AperTO - Archivio Istituzionale Open Access dell'Università di Torino

\title{
Emerging foliar and soil-borne pathogens of leafy vegetable crops: a possible threat to Europe
}

\section{This is a pre print version of the following article:}

Original Citation:

\section{Availability:}

This version is available http://hdl.handle.net/2318/1664980

since 2018-11-02T11:51:01Z

Published version:

DOI:10.1111/epp.12447

Terms of use:

Open Access

Anyone can freely access the full text of works made available as "Open Access". Works made available under a Creative Commons license can be used according to the terms and conditions of said license. Use of all other works requires consent of the right holder (author or publisher) if not exempted from copyright protection by the applicable law. 


\section{IIIS AperTO}

UNIVERSITÀ

DEGLI STUDI

DI TORINO

This is the author's final version of the contribution published as:

Emerging foliar and soil-borne pathogens of leafy vegetable crops: a possible threat to Europe

Giovanna Gilardi, Maria Lodovica Gullino, Angelo Garibaldi Bulletin OEPP/EPPO Bulletin (2018) 0 (0), 1-12, ISSN 0250-8052. DOl: 10.1111/epp.12447

The publisher's version is available at:

https://doi.org/10.1111/epp.12447

When citing, please refer to the published version.

Link to this full text:

https://onlinelibrary.wiley.com/doi/full/10.1111/epp.12447

\section{iris-AperTO}


Running head: New pathogens of leafy vegetables

Emerging foliar and soil-borne pathogens of leafy vegetable crops: a possible threat to Europe Giovanna Gilardi $^{{ }^{*}}$, Maria Lodovica Gullino ${ }^{1,2}$, Angelo Garibaldi ${ }^{1}$

${ }^{1}$ Centre for Innovation in the Agro-Environmental Sector, AGROINNOVA, University of Torino, Largo P. Braccini 2, 10095 Grugliasco (TO), Italy

${ }^{2}$ Department of Agricultural, Forest and Food Sciences (DISAFA), University of Torino, Largo P. Braccini 2, 10095, Grugliasco (TO), Italy

*Corresponding author: Giovanna Gilardi

Tel.: +300116708547

Fax: +390116709307

E-mail address: giovanna.gilardi@ unito.it 


\begin{abstract}
Italy is one of the leading countries in the production and consumption of ready-to-eat salads. This has led to a steady increase in the surfaces used for the growth of leafy vegetables, under intensive systems, over the last decade. The recent evolutions of the diseases that affect lettuce, wild and cultivated rocket, lamb's lettuce, spinach and basil are here reported. Plecosphaerella cucumerina, on wild rocket, endive and lamb's lettuce, Fusarium equiseti on wild and cultivated rocket and lettuce, Myrothecium verrucaria on spinach and wild rocket, Myrothecium roridum on lamb's lettuce, Allophoma tropica on lettuce and Alternaria sp. on basil and rocket, are among the new foliar pathogens and are described hereafter. Among the soil-borne pathogens, Pythium aphanidermatum, P. irregulare, Pythium Cluster B2a have frequently been isolated on spinach and swiss chard, lamb's lettuce and lettuce, while Fusarium oxysporum f. sp. lactucae, which causes lettuce wilt, is gradually spreading to new countries. Some of the new pathogens have been found to be seed transmitted and typical of tropical areas, and are thus favoured by the rises in temperature that currently characterize the climate change scenario. The globalisation of markets, climate change and intensive cultivation are among the factors that are responsible for the proliferation and spread of some of those new pathogens that are 'aliens' to Italian production systems.
\end{abstract}

\title{
Introduction
}

Over the last few decades, significant changes have occurred in agriculture, as well as in society's and policy-makers' attitudes, and as a consequence, in disease management strategies. Agriculture continues to change in response to society's needs (Stoate et al., 2009). The promotion of improved health lifestyles has led to an increased demand for fresh products in many industrialized countries. Agricultural intensification is particularly noticeable in crops such as leafy vegetables (lettuce, rocket, spinach, lamb's lettuce, basil...), and is linked to the increase in the industrial production of fresh cut and ready-to-eat processed salad, with retail being the main distribution channel. Fresh-cut products are fruit or vegetables that have been trimmed, peeled and/or cut into a fully usable product, which is subsequently packaged to offer consumers high nutrition, convenience and flavour (IFPA 2001). The European fresh-cut industry has undergone exponential growth since the early 1980s. Italy, together with Great Britain, is the leader in Europe for fresh, ready-to-eat salads, producing 90000 tonnes in 2013, with a turnover of $€ 770$ million (Nomisma, 2015). Italy, with a $21 \%$ increase in the consumption of fresh-cut salads from 2008 to 2013, has become the leading European country as far as annual pro capita consumption is concerned, with an average of $1.6 \mathrm{~kg}$ of fresh-cut salads consumed per person per year (Nomisma, 2015).

\section{iris-AperTO}


Leafy vegetable crops all share some specific features, such as high value, continuous intensification and innovation in their production systems, the presence of a high number of varieties, delocalization of seed production in southern countries, susceptibility to a number of pathogens and limitations in the use of chemicals for their control (Gullino et al., 2014 a). Among the consequences of the dynamism and specialization of such crops, together with the lack of adequate crop rotation and the globalization of the seed market, the appearance of many new pathogens that cause severe field losses is one of the most critical.

The phytosanitary situation of leafy vegetables has constantly been monitored in different Italian and European production areas over the past 15 years. This review will focus on the most important foliar and soil-borne diseases observed on lettuce (Lactuca sativa L.), wild (Diplotaxis spp.) and cultivated (Eruca sativa Mill.) rocket, lamb's lettuce (Valerianella olitoria L.), basil (Ocimum basilicum L.) and spinach (Spinacia oleracea L.), and will present an update of recent investigations on this topic (Garibaldi \& Gullino, 2010; Garibaldi et al., 2014 a; Gullino et al., 2014 b; Gullino et al., 2017 c) (Table 1). Control measures, based on the current scientific knowledge, have been reported.

\section{Foliar diseases}

\section{Leaf spot caused by Plectosphaerella cucumerina}

A foliar disease caused by Plectosphaerella cucumerina has recently been observed in Italy on wild rocket, endive (Gullino et al., 2014 a) and lamb's lettuce (Carrieri et al., 2014) (Table 1), with consequent severe losses. The affected leaves show spots that are usually surrounded by a yellowgrey halo, and which are predominantly located on the leaf surface, rib and petiole. Damaged tissues rot quickly after packaging, but also during transit and commercialization (Figures 1 and 2). The fast south-north spread of the disease that occurred in Italy on wild rocket in 2012 has been explained by the capability of the pathogen to infect seeds (Tables 1 and 2) (Gullino et al., 2014 a). This filamentous Ascomycete is cosmopolitan in distribution, and it has been reported on many hosts (Palm et al., 1995; Carlucci et al., 2012; Pétriacq et al., 2016; Farr \& Rossman, 2017). This species can change from hemibiotrophic to necrotrophic (Pétriacq et al., 2016), thus causing a wide range of symptoms, including crown and root rot, as well as leaf necrosis, on a large number of hosts such as melon, watermelon, squash, courgette, cucumber, sunflower, white lupin, parsley (Carlucci et al., 2012), and banana (Farr \& Rossman, 2017). It was first observed in Italy on basil and tomato, where it causes basal rot (Matta, 1978). P. cucumerina is a nematophagous fungus that had previously been considered as a potential biological control agent (Atkins et al., 2003).

\section{iris-AperTO}


Its ability to survive as a saprotroph in soil (Domsch \& Gams, 1972), its polyphagous nature and its capability to contaminate seeds (Table 2) makes its management difficult. Among chemicals tested against Plectosphaerella leaf spot on wild rocket, phosphite-based products, acibenzolar-S-methyl, mandipropamid and azoxystrobin, have provided the most consistent, although not complete control (Gilardi et al., 2015 a). Also copper hydroxide and terpenic alcohols and Streptomyces griseoviridis, that are products permitted in organic farming, provided a positive effect in reducing the leaf spot by P. cucumerina on rocket (Gilardi et al., 2015 a), while, in other studies, Trichoderma asperellum (strain T34) and different Streptomyces species (S. cyanoviridis, $S$. murinus and S. griseoplanus) have been found to be effective against Plectosporium tabacinum on white lupin (Youssef et al., 2001) and cucumber (Segarra et al., 2013). An integrated approach is necessary, considering the difficulty of reaching complete control of this pathogen with single control measures.

\section{Leaf spot caused by Alternaria species}

The species in the genus Alternaria represent a potential threat to leafy vegetables in several production areas in Italy, as well as in other countries. A. alternata was first observed on sweet basil in 2010 (Gullino et al., 2014 a). The pathogen causes brown-black lesions, which, on older leaves, are surrounded by a yellow halo, causing the progressive defoliation of the plants, and, on rare occasions, to the death of plants (Figure 3). The disease was first observed on the leaves of plants grown in soilless systems, as well as in soil in Piedmont (Northern Italy) on the most extensively grown variety for fresh consumption and pesto production (Table 1). The pathogen has been isolated from several commercial seed lots (Table 2), with a high level of contamination (from 7.3\% and $2.6 \%$ of non-disinfected and disinfected seeds), thus suggesting that seeds may be important in its dissemination in different cultivation areas (Gullino et al., 2014 a). The Alternaria leaf spot of basil had previously been reported in California, Florida, Pakistan, Japan and Israel (Farr \& Rossman 2017; Taba et al., 2009; Kenigsbuch et al., 2010). In the same year, Alternaria japonica was isolated from a number of samples taken throughout the growing season over different years from wild and cultivated rocket plants in Italy (Figure 4) (Gullino et al., 2014 a). The same pathogen has recently affected the growth and quality of hydroponically grown cultivated rocket in California (Tidwell et al., 2014). Rocket plants can be affected in all the growth stages, and the typical symptoms include black necrotic lesions surrounded by chlorotic areas on seedlings, leaves and stems (Gullino et al., 2014 a). Seeds may be important in disseminating the pathogen because

\section{iris-AperTO}


the external contamination of wild and cultivated rocket seeds has been observed (Table 2) (Gilardi et al., 2015 b). Although A. japonica has been found to be the most prevalent species among the Alternaria isolates from wild and cultivated rocket plants and seeds, pathogenic isolates of $A$. tenuissima, A. brassicicola and A. arborescens have also been identified, thus suggesting that these Alternaria species are also a potential threat to rocket (Siciliano et al., 2017 c). Moreover, almost all the isolates collected from rocket plants and seeds were able to produce Alternaria toxins (tenuazonic acid, alternariol, alternariol monomethyl ether, altenuene and tentoxin) in vitro (Sicicliano et al., 2017 c). This pathogen may be a threat to wild and cultivated rocket production, because, once introduced into the field, it can persist on plant debris or through chlamydospores, and it can also spread by means of airborne conidia (Simmons, 2007). The management of Alternaria spp. requires a combination of agricultural management practices (i.e. the adoption of healthy seeds and propagation material, use of resistant cultivars whenever possible, use of appropriate crop rotation, removal and destruction of infested plant material), and multiple fungicide sprays. Fungicides registered for use against Alternaria spp. include sterol demethylation inhibitors (DMIs), quinine outside inhibitors (QoI), dicarboximides and carboxamide (Rimmer et al., 2007). A limited availability of chemicals for use on 'minor crops' might increase the risk of development of resistance.

\section{Leaf spot caused by Fusarium equiseti}

Fusarium equiseti could represent a serious threat for many Mediterranean crops. First found in Northern Italy on cultivated rocket in 2010 (Gullino et al., 2014 a), it was later reported on wild rocket (Garibaldi et al., 2015 b) and lettuce (Garibaldi et al., 2016 e) in Northern and Southern Italy (Table 1): in all these cases, the symptoms consisted of leaf spots (Figures 5 and 6). Yield losses of about $10 \%$ have been observed at temperatures of between 15 and $30^{\circ} \mathrm{C}$ and under high relative humidity. Since $F$. equiseti is a member of the Fusarium incarnatum-equiseti species complex (FIESC), phylogenetic analysis, based on multilocus DNA sequencing, has been used widely for its identification (O’ Donnell et al., 2012).

F. equiseti is a well-known seed-borne pathogen that is found on many host plants (Farr \& Rossman, 2017). The pathogen has been found as an external contaminant of Diplotaxis spp. seeds (Gilardi et al., 2017 c) (Table 2). Once introduced in the field, its survival is favoured because this pathogen is able to survive in soil or crop debris. Such a feature makes it adapt easily to different cropping systems, in particular to those of a very intensive nature. Moreover, this species generally 
occurs in tropical and subtropical regions on a wide range of plants (cotton, lentils, sugar beet, cumin, potatoes, cowpeas, pines, ginseng, asparagus...) on which it causes a variety of symptoms (Bottalico 1988; Goswami et al., 2008; Farr \& Rossman, 2017) and spreads rapidly in warm and humid environments. Lettuce and rocket are very susceptible to $F$. equiseti at temperatures ranging from 25 to $35^{\circ} \mathrm{C}$, and 1 to 3 hours of high relative humidity are sufficient to damage the yield quality of such crops in the presence of the pathogen; while longer periods under high relative humidity (6-12 hours) are necessary at lower temperatures of 15 to $20^{\circ} \mathrm{C}$ to cause significant losses (Garibaldi et al., 2016 a). Along with the broad host range, the conditions that are favourable for the pathogen make disease management very difficult. Managing the environment by avoiding high temperatures and keeping the relative humidity to a minimum recommended level are among the preventative measures that have been suggested (Garibaldi et al., 2016 a). Since it is not always possible to control the environmental parameters, growers often have to rely on chemical control. However, the chemical management of this pathogen is still under investigation. Fludioxonil, benomyl, thiophanate-methyl, propiconazole and fludioxonil are able to reduce the in vitro mycelial growth of $F$. equiseti taken from ginseng (Punja et al., 2008). The ability of $F$. equiseti to produce diverse mycotoxins, including trichothecenes, leads to further health risks (Bosch \& Mirocha, 1992; Bottalico, 1988; Bottalico \& Perrone, 2002; Goswami et al., 2008).

\section{Leaf spot caused by Myrothecium species}

The number of first reports regarding Myrothecium verrucaria and M. roridum on new hosts has increased in recent years. Myrothecium roridum has been found on lamb's lettuce (Garibaldi et al., 2016 b), while M. verrucaria has been isolated from spinach (Garibaldi et al., 2016 c) and wild rocket (Garibaldi et al., 2016 d). These Myrothecium species were both first observed in Italy in 2015 under plastic tunnels (Table 1). The symptoms caused by both species are similar: circular, sunken, grey-brown spots, with a well-defined border, that develop on affected leaves. Creamy to black sporodochia appear on the leaf surface, in concentric rings, under high relative humidity (Figures 7-9).

Myrothecium spp. are soil inhabiting fungi, and are the causal agents of leaf spots and stem rot on several different plant hosts, such as cotton, tomato, cacao, coffee, potato, soybean, cucurbits and corn, as well as on many ornamentals (Farr \& Rossman, 2017). There is no evidence of host specificity for these species, and this also makes the use of resistant cultivars difficult (Chase, 1983; Yang \& Jong, 1995; Fish et al., 2012). However, moderately level of resistance to Myrothecium 
leaf spot caused by $M$. roridum in some cucurbit crops and ornamental plants is reported (Norman et al., 2003; Fish et al., 2012). The management of Myrothecium leaf spot is complicated, because this pathogen is seed-transmitted in many cases (Nguyen et al., 1973; Belisario et al., 1999; Bharath et al., 2006). Moreover, no information is available for the control of Myrothecium leaf spot on leafy vegetables by chemicals means, and further investigations are needed.

Myrotechium leaf spot may become important in the future considering the forecasted climate change scenario (Siciliano et al., 2017 b). Another characteristic that makes this genus a serious threat is linked to its capability to produce macrocyclic trichothecenes, which are cytotoxic compounds. The biosynthesis of verrucarin A mycotoxin has been found to increase significantly at $35{ }^{\circ} \mathrm{C}$, with an average concentration of $19.5 \mu \mathrm{g} / \mathrm{g}$ compared to $7.1 \mu \mathrm{g} / \mathrm{g}$ at temperature of 10 ${ }^{\circ} \mathrm{C}$, while at $\mathrm{CO}_{2}$ concentration of $800 \mathrm{ppm}$, roridin $\mathrm{E}$ biosynthesis increased from $28.4 \mu \mathrm{g} / \mathrm{g}$ at 22$26^{\circ} \mathrm{C}$ to $49.6 \mu \mathrm{g} / \mathrm{g}$ at $26-30{ }^{\circ} \mathrm{C}$, thus indicating a possible positive correlation between climate change and macrocyclic trichothecene production (Siciliano et al., 2017 b).

\section{Leaf spot caused by Phoma species}

Species from the Phoma genus are found worldwide, and these pathogens have recently received increased attention because they can cause extensive losses (Chen et al., 2015; Farr \& Rossman, 2017). The Phoma genus is also well known because it includes species of quarantine concern (Aveskamp et al., 2008). Phoma valerianellae and Pleospora betae have repeatedly been observed on lamb's lettuce and on swiss chard, respectively, on many farms in Italy in spring and autumn crops under plastic tunnels (Gullino et al., 2014 a) (Table 1), thus severely reducing the quality of the plants. The symptoms appear on young plants as blackening and necrosis of the cotyledons, stem and roots, while red-brown necrosis may be observed on older plants on the lower leaves and on the stem base eventually causing plant collapse. Both these causal agents are seed-borne, and their introduction into the field can be due to the use of infected seeds (Neergaard, 1979; Nathaniels, 1985) (Table 2).

Allophoma tropica (syn. Phoma tropica) has recently been observed in Northern Italy on lettuce (Gullino et al., 2014 a) (Table 1). Although the economic importance of this disease is still limited, it has been observed that this pathogen increases in frequency in years characterized by relatively low temperatures in spring and summer. The pathogen is more aggressive between 20 to $25^{\circ} \mathrm{C}$ (Gullino et al., 2017 b), that is, at a temperature that is also optimum for its growth in vitro (Schneider \& Boerema, 1975). A. tropica was first associated with leaf spots and stem lesions on

$$
\text { iris-AperTO }
$$


different ornamental plants in the Netherlands and Germany (Schneider \& Boerema, 1975), and has so far been detected on several hosts (Farr \& Rossman, 2017). Growers and agricultural advisory services need to be particularly careful when attempting to identify A. tropica, because the leaf spot it causes on lettuce (Figure 10) can be confused with the grey mould caused by Botryotinia fuckeliana.

Since controlling the environmental conditions does not always provide adequate disease suppression of Phoma spp., fungicides are also needed. Mancozeb, fludioxonil, iprodione, pyraclostrobin and boscalid, which are known to be effective against Botrytis grey mould, resulted also effective against A. tropica. Moreover, the efficacy shown by copper-based products is of special interest, particularly for crops grown under organic farming conditions (Pintore et al., 2017).

\section{Downy mildew of basil}

Basil downy mildew which is caused by Peronospora belbahrii (Belbahri et al., 2005; Thines et al., 2009), is one of the most economically important basil diseases, and has caused significant yield losses in several countries in Europe, (Switzerland, Italy, France and Belgium), in the United States, where it has been reported in several States since 2009, in Argentina, Israel (Cohen et al., 2013) and China (Farr \& Rossman, 2017). The transmission of this pathogen via infected seeds is generally recognised as the main means of survival of $P$. belbahrii from season to season, because the pathogen rarely produces oospores (Cohen et al., 2013; Djalali et al., 2012; Gullino et al., 2014 a; Wyenandt et al., 2015; Elad et al., 2016). Moreover, it has been shown that basil seeds are a potential source of mefenoxam-resistant inoculum for P. belbahrii (Pintore et al., 2016).

Because no cultivars of marketable interest are known to be resistant or tolerant to downy mildew (Ben-Naim et al., 2015), the control of downy mildew is mainly based on the application of fungicides, such as for examples mefenoxam, potassium phosphite, mandipropamid, fluopicolid, mancozeb and azoxystrobin (Gilardi et al., 2013; 2015 c; Wyenandt et al., 2015). Furthermore, the resistance inducer, acibenzolar-S-methyl, significantly reduces the disease (Mersha et al., 2013; Gilardi et al., 2013). The use of chemicals in the field is complicated by the continuous nature of the harvest, and by the high risk of development of pathogen strains resistant to the fungicides through specific modes of action. For instance, the field resistance of $P$. belbahrii to phenylamides was first observed in Israel in 2013 (Cohen et al., 2013), and later in Italy (Garibaldi et al., 2016). An integrated approach to basil downy mildew control is suggested in which the microclimate environmental conditions are managed. This is because infection, sporulation and the duration of 
the latent period (from infection to sporulation) of $P$. belbahrii is dependent to a great extent on the occurrence of high levels of humidity (>85\%), on temperature and light regime. For instance, spore germination and infection occur at temperatures from 5 to $28.5^{\circ} \mathrm{C}$, sporulation occurs at 10 to $26^{\circ} \mathrm{C}$ (optimum of $18^{\circ} \mathrm{C}$ ), and the shortest latent period is 5 days at $25^{\circ} \mathrm{C}$ under continuous light (Garibaldi et al., 2007; Cohen et al., 2013; Cohen et al., 2017). Nocturnal illumination and fanning, a daytime solar heating of $35-45^{\circ} \mathrm{C}$ for $6-9$ hours and for 3 consecutive days, increasing the temperature $\left(26\right.$ to $31^{\circ} \mathrm{C}$ ) in the root zone of basil using passive heat treatment, are among the practices suggested to prevent or suppress the disease under controlled environmental conditions (Cohen et al., 2013; 2016; Cohen \& Rubin, 2015; Elad et al., 2016).

\section{Soil-borne pathogens}

Among the soil-borne diseases, damping off, caused by Pythium ultimum, has been observed with increasing frequency in Italy on lettuce, wild rocket and lamb's lettuce at temperatures of between 15 and $25{ }^{\circ} \mathrm{C}$. The presence of new species of Pythium in Italy, such as P. aphanidermatum on spinach (Garibaldi et al., 2015 c) and on swiss chard, P. irregulare on lamb's lettuce (Garibaldi et al., 2015 a) and Pythium Cluster B2a on lettuce (P. dissotocum, P. coloratum, P. diclinum, P. cf. dictyosporum, $P$. lutarium, $P$. sp. 'Group F' and $P$. sp. tumidum) (Table 1), is particularly critical (Garibaldi et al., 2017) at warm temperatures (Figures 11 -12).

Moreover, Fusarium oxysporum f. sp. lactucae has also increasingly been observed in lettuce cultivation areas (Matheron \& Gullino, 2012), and has recently spread to the Netherlands (Gilardi et al., 2017a) and France (Gilardi et al., 2017 d). Like other soil-borne pathogens, Fusarium wilt is difficult to manage with a single approach and/or with a single product (Katan, 2017). Moreover, different measures are needed for different cropping systems (Matheron \& Gullino, 2012; Gordon $\&$ Koike 2015). Among chemical measures, available soil disinfestation is becoming very difficult due to the loss of registered fumigants. In addition, chemical control may be limited by the observation that Pythium spp. can develop resistance to common fungicides as regularly updated in the FRAC Resistance Survey List (www.frac.info). Various non-chemical strategies, including sanitation, cultural practices, the use of resistant cultivars and biological control agents are being intensively investigated (Katan, 2017). For instance, the use of resistant cultivars represents the most effective choice to control lettuce Fusarium wilt (Matheron \& Gullino, 2012; Gordon \& Koike 2015). Nevertheless, a careful monitoring of the race situation in the field is also necessary for an

\section{iris-AperTO}


efficient use of genetic control approaches. However, resistant cultivars are generally not available for most leafy vegetables against Pythium spp..

\section{Factors favouring the emergence of new pathogens}

There is much evidence concerning the causes of the development and spread of new diseases, including the globalisation of the seed and planting material markets, the effect of climate change, and changes in cultural and management practices. Global travel and the trade of agricultural seeds and products have moved crops and pathogens away from their original environments. The examples described for leafy vegetables suggest that most of the fungal pathogens that cause severe losses are seed-borne (Gullino et al., 2014 a). Moreover, very low levels of contamination can lead to the rapid emergence of new diseases in different geographic areas. In this respect, the downy mildew of basil and Fusarium wilt of lettuce represent two very interesting case studies.

Considering the losses caused by these emerging pathogens (Table 1), the first preventative strategy that should be considered by seed producers and farmers is the use of healthy seeds. Stock seeds should be produced in the areas associated with the lowest disease risk, and the seeds subjected to standardised seed health analysis (Munkvold, 2009). The availability of good diagnostic tools and an early pathogen detection represent the best preventative measures in many cases (Thomas et al., 2017), as has been observed for the case of P. cucumerina on wild rocket (Gilardi et al., 2016 b) as well as for formae speciales and races of Fusarium oxysporum from seeds, plants and soil samples (Pasquali et al., 2007; Mbofung \& Pryor, 2010; Gilardi et al., 2017 a).

In order to further reduce the risk from seed-borne pathogens, it is recommended that stock seeds should undergo precautionary decontamination treatments. Chemical seed treatments have successfully been applied to vegetable seeds and are in commercial use for a wide range of crops against different seed-borne pathogens (Munkvold, 2009; Koch \& Roberts, 2014). Heat treatments with hot water, aerated steam or dry heat can be very effective, but they need to be optimised due to the differences in temperature and time required for different target pathogens and crops (Nega et al., 2003; Koch \& Roberts, 2014). Although the current non-chemical seed treatments, including the use of resistance inducers, antagonistic microorganisms, as well as fungal and plant extracts are presently being investigated intensively for seeds produced under organic farming rules, there are only a few examples of commercial use (Koch \& Roberts, 2014; Gullino et al., 2014 b). For instance, several options for non-chemical control of Alternaria brassicicola on Brassica seeds resulted comparable in efficacy to the chemical standard (Amein et al., 2011). Moreover, the inclusion of non-chemical seed treatments such as dry heat air $\left(65^{\circ} \mathrm{C}\right.$ for $\left.10 \mathrm{~min}\right)$, resistance

$$
\text { iris-AperTO }
$$


inducers and thyme oil seed treatments, in basil downy mildew management programmes, merits further investigation (Gilardi et al., 2015 c; Lopez et al., 2016).

Given the predicted increase in global air temperatures and $\mathrm{CO}_{2}$ concentrations, downy mildew on basil, Alternaria leaf spot on rocket and Phoma leaf spot on swiss chard and lettuce, Myrothecium leaf spot on spinach, Fusarium equiseti leaf spot on wild rocket and lettuce are expected to become more problematic due to a good adaptation capacity under different environmental conditions, but also under a climate change scenario (Gilardi et al., 2016 a; Gilardi et al., 2017 b; Gullino et al., 2017 b; Siciliano et al., 2017 a,b, c). Moreover, the increase in temperatures predicted for the future could also induce an increase in the incidence of diseases caused by plant pathogenic Fusarium species, probably through plant-mediated effects (Chitarra et al., 2015; Ferrocino et al., 2013). In particular, climate change is likely to have direct influence on the spatial and temporal dispersal of propagules, on the rapidity of disease development, and on the pathogen survival or indirectly affect both the host and the pathogen by changing, for example, the frequency of suitable infection conditions (West et al., 2012). Moreover, climate change is expected to affect strategies for disease control; for instance, it can reduce host resistance because some resistance genes are temperature sensitive and may indirectly affect the efficacy of applied agrochemicals under slightly warmer temperatures (Coakley et al., 1999; Garret et al., 2006; West et al., 2012; Gilardi et al., 2017 b).

\section{Conclusions}

The risks posed by epidemic outbreaks of plant diseases have recently been reviewed by Zadoks (2017) who has pointed out the negative implications on agriculture, on the environment, on international trade, as well as the social and political consequences. This perspective emphasizes the important need to understand the disease dynamics of new pathogens to improve effective disease management measures (Gamliel, 2008; Gullino et al., 2017c; Mumford et al., 2017).

For instance, F. equiseti and Myrothecium are currently spreading quickly in Italy on different leafy vegetables that are grown intensively under monocultures or in succession. Such a feature makes these pathogens a serious threat for many Mediterranean crops, because most of the emerging leafy vegetable pathogens have shown a broad host range and they can easily adapt to many different cropping systems, and in particularly to those of a very intensive nature. Furthermore, F. equiseti represents a clear example of a fungus that in the past was considered a weak pathogen, but which has now become more serious and invasive.

\section{iris-AperTO}


The expected increases in climatic variability are of even more concern, as they could lead to an increase in the number of losses due to diseases and pests in a given locality, as well as to the year by year variations of their occurrence. Additionally, the ability of some of the newly introduced pathogens to produce a diversity of mycotoxins increases the health risk to consumers.

Given the substantial losses caused by the increased number of epidemic invasions that have resulted from globalisation (Gullino et al., 2014 a), and by the significant impact of global climate changes (West et al., 2012), intense efforts are needed to prevent diseases and to provide control measures.

The multiple mechanism by which seed-borne pathogens survive and disseminate cause both opportunities and difficulties in their disease management. Attempts to control pathogen populations are include the use of pesticides, resistance genes, crop rotations and a variety of cultural practices aimed at reducing plant infections.

As these foliar emerging pathogens of leafy vegetables are generally associated with warmer environments and short wetting periods, the management of microclimate environmental conditions, may become very important.

Using resistant cultivars for the management of soil-borne and foliar pathogens of leafy vegetables would be the most practical, effective and economical approach in both conventional and organic farming. Unfortunately, there is no information available on cultivars that are less susceptible to these new or re-emerging foliar pathogens of leafy vegetables, despite the intensive research that has been conducted on some diseases (i.e. basil downy mildew), and further investigations are necessary. Moreover, the rapid substitution of varieties to adapt to the market demand and the use of mono and oligo-genic resistances to diseases, which may favour the rise of special new forms and new families of pathogens, could complicate its practical application.

Since these measures do not always provide adequate disease suppression, fungicides are also needed, as part of Integrated Pest Management (IPM). Diversity of fungicides, concerning their chemistry and mode of action, is essential to ensure effective crop protection, to control the new threats and to manage fungicide resistance (Leadbeater \& Gisi, 2009). However, it is possible, by means of epidemiological studies, to elaborate an efficient disease management programme which would allow the number of chemical treatments to be reduced (Ojiambo et al., 2017).

Effort for a continuous monitoring and disease surveillance is necessary. Quick and reliable diagnostic tools, measures to produce healthy seeds and seed treatment methods need to be investigated and made available to seed companies and growers. 
Adopting preventative and combined methods of disease management has become the tool of choice for the control of a wide spectrum of pests. This is essential for the productive sector of leafy vegetables, affected by several new diseases.

\section{Acknowledgments}

This research has received funding from the European Union's Horizon 2020 research and innovation programme under grant agreement No. 634179. Effective Management of Pests and Harmful Alien Species - Integrated Solutions^ ${ }^{\wedge}$ (EMPHASIS). The authors would like to thank Marguerite Jones for the language revision.

\section{Reference}

Amein T, Wright SAI, Wikstr “om M, Koch E, Schmitt A, Stephan D et al., (2011) Evaluation of non-chemical seed treatment methods for control of Alternaria brassicicola on cabbage seeds. Journal of Plant Disease and Protection 118, 214-221.

Atkins SD, Clark IM, Sosnowska D, Hirsch PR \& Kerry BR (2003) Detection and quantification of Plectosphaerella cucumerina, a potential biological control agent of potato cyst nematodes, by using conventional PCR, Real-Time PCR, selective media, and baiting. Applied and Environmental Microbiology 69, 4788-4793.

Aveskamp MM, De Gruyter J, Crous PW (2008) Biology and recent developments in the systematic of Phoma, a complex genus of major quarantine significance. Fungal Diversity 31, 1-16. Belbahri I, Calmin G, Pawlowski J, Lefort F (2005) Phylogenetic analysis and real time PCR detection of a presumably undescribed Peronospora species on sweet basil and sage. Mycological Research 109, 1276-1287.

Belisario A, Forti E, Corazza L (1999) First report of Myrothecium verrucaria from muskmelon seeds. Plant Disease 83, 589.

Ben-Naim Y, Falach L, Cohen Y (2015) Resistance against basil downy mildew in Ocimum Species. Phytopathology 105, 778-785.

Bharath BG, Lokesh S, Raghavendru VB, Prakah HS \& Shetty BG (2006) First report of the occurrence of Myrothecium verrucaria in watermelon seeds from India. Australasian Plant Disease Notes 1, 3-4.

Bosch U \& Mirocha CJ (1992) Toxin production by Fusarium species from sugar-beets and natural occurrence of zearaenone in beets and beet fiber. Applied Environmental Microbioogy 58, 32333239. 
Bottalico A \& Perrone G (2002) Toxigenic Fusarium species and mycotoxins associated with head blight in small-grain cereals in Europe. European Journal PlantPathology 108, 611-624.

Bottalico A (1988) Fusarium diseases of cereals: species complex and related mycotoxin profiles in Europe. Journal of Plant Pathology 80, 85-103.

Carlucci A, Raimondo ML, Santos J \& Phillips AJL (2012) Plectosphaerella species associated with root and collar rots of horticultural crops in southern Italy. Persoonia 28, 34-48.

Carrieri R, Pizzolongo G, Carotenuto G, Tarantino P \& Lahoz E (2014) First report of necrotic leaf spot caused by Plectosphaerella cucumerina on lamb's lettuce in Southern Italy. Plant Disease 98, 998.

Chase AR 1983. Influence of host plant and isolate source on Myrothecium leaf spot of foliage plants. Plant Disease 67, 668-671.

Chen Q, Jiang JR, Zhang GZ, Cai L \& Crous PW (2015) Resolving the Phoma enigma. Studies in Mycology 82, 137-217.

Chitarra W, Siciliano I, Ferrocino I, Gullino ML \& Garibaldi A (2015) Effect of elevated atmospheric $\mathrm{CO}_{2}$ and temperature on disease severity of rocket plants caused by Fusarium wilt under phytotron conditions. PLOS ONE 10:e0140769.

Coakley S M, Scherm H, \& Chakraborty S (1999) Climate change and plant disease management. Annual Review of Phytopathology 37, 399-426.

Cohen Y \& Rubin AE (2015) Daytime solar heating controls downy mildew Peronospora belbahrii in sweet basil. PLOS ONE 10, e0126103.

Cohen Y, Vaknin M, Ben-Naim Y \& Rubin AE (2013) Light suppresses sporulation and epidemics of Peronospora belbahrii. PLoS ONE 8, e81282.

Cohen Y, Vaknin M, Ben-Naim Y \& Rubin AE (2016) Nocturnal fanning suppresses downy mildew epidemics in sweet basil. PLOS ONE 11, e0155330.

Cohen Y, Vaknin M, Ben-Naim Y \& Rubin AE (2017) Epidemiology of basil downy mildew. Phytopathology 107, 1149-1160.

Cohen Y, Vaknin M, Ben-Naim Y, Rubin AE, Galperin M, Silverman D, Bitton S \& Adler U (2013) First report of the occurrence and resistance to mefenoxam of Peronospora belbahrii, causal agent of downy mildew of basil (Ocimum basilicum) in Israel. Plant Disease 97, 692.

Djalali Farahani-Kofoet DR, Römer P \& Grosch R (2012) Systemic spread of downy mildew in basil plants and detection of the pathogen in seed and plant samples. Mycological Progress 11, 961-966. 
Domsch K H \& Gams W (1972) Fungi from agricultural soils. Longman, pp. 290. London, United Kingdom.

Elad Y, Omer C, Nisan Z, Harari D, Goren H, Adler U, Silverman D \& Biton S (2016) Passive heat treatment of sweet basil crops suppresses Peronospora belbahrii downy mildew. Annals Applied Biology 168, 373-389

Farr DF \& Rossman AY (2017) Fungal Databases U.S. National Fungus Collections, ARS, USDA. http://nt.ars-grin.gov/fungaldatabases (Last accessed 20/April/2017).

Ferrocino I, Chitarra W, Pugliese M, Gilardi G, Gullino ML \& Garibaldi A (2013) Effect of elevated atmospheric $\mathrm{CO} 2$ and temperature on disease severity of Fusarium oxysporum f. sp. lactucae on lettuce plants. Applied soil ecology 72, 1-6.

Fish WW, Bruton BD \& Popham TW (2012) Cucurbit host range of Myrothecium roridum isolated from watermelon. American Journal of Plant Sciences 3, 353-359.

Gamliel A (2008) High consequence plant pathogens. In Crop biosecurity: assuring our global food supply (Eds Gullino M.L., Fletcher J., Gamliel A., Stack J.P.), pp. 25-36. Springer, Dordrecht, The Netherlands.

Garibaldi A \& Gullino ML (2010) Emerging soilborne diseases of horticultural crops and new trends in their management. Acta Horticolturae 883, 37-47.

Garibaldi A, Bertetti D \& Gullino ML (2007) Effect of leaf wetness duration and temperature on infection of downy mildew (Peronospora sp.) of basil. Journal of Plant Diseases and Protection 114, 6-8.

Garibaldi A, Gilardi G \& Gullino ML (2014) Critical aspects in disease management as a consequence of the evolution of soil-borne pathogens. Acta Horticulturae 1044, 43-50.

Garibaldi A, Gilardi G, Berta F \& Gullino ML (2016 a) Temperature and leaf wetness affect the severity of leaf spot on lettuce and wild rocket incited by Fusarium equiseti. Phytoparasitica 44, 681-687.

Garibaldi A, Gilardi G, Franco Ortega S \& Gullino ML (2016 b). First report of leaf spot of lamb's lettuce (Valerianella olitoria) caused by Myrothecium roridum in Italy. Plant Disease 100, 1237. Garibaldi A, Gilardi G, Franco-Ortega S \& Gullino ML (2015 a) Root Rot of Lamb's Lettuce (Valerianella olitoria) in Northern Italy Caused by Pythium irregulare. Plant Disease 99, 1650 Garibaldi A, Gilardi G, Franco-Ortega S \& Gullino ML (2016 c) First report of leaf spot of spinach (Spinacia oleracea) caused by Myrothecium verrucaria in Italy. Plant Disease 100, 1786. 
Garibaldi A, Gilardi G, Franco-Ortega S \& Gullino ML (2016 d) First report of leaf spot of wild rocket (Diplotaxis tenuifolia) caused by Myrothecium verrucaria in Italy. Journal of Plant Pathology 98, 677-697.

Garibaldi A, Gilardi G, Matic S \& Gullino ML (2017) First report of stem rot caused by a Pythium Cluster B2a species on lettuce in Italy. Plant Disease 101, 1681.

Garibaldi A, Gilardi G, Ortu G \& Gullino ML (2015 b) First report of leaf spot of wild rocket (Diplotaxis tenuifolia) caused by Fusarium equiseti in Italy. Plant Disease 99, 1183-1184.

Garibaldi A, Gilardi G, Ortu G \& Gullino ML (2015 c) Root rot of spinach in Southern Italy caused by Pythium aphanidermatum. Plant Disease 99, 159.

Garibaldi A, Gilardi G, Ortu G \& Gullino ML (2016 e) First Report of leaf spot of lettuce (Lactuca sativa) caused by Fusarium equiseti in Italy. Plant Disease 100, 513.

Garibaldi A, Pintore I, Gilardi G \& Gullino ML (2016 f) Resistenza a mefenoxam in popolazioni di Peronospora belbahrii. Protezione delle Colture 9 (5), 13-16.

Garrett K A, Dendy S P, Frank E E, Rouse M N \& Travers SE (2006) Climate change effects on plant disease: genomes to ecosystems. Annual Review of Phytopathology 44, 489-509.

Gilardi G, Demarchi S, Garibaldi A \& Gullino ML (2013) Management of downy mildew of sweet basil (Ocimum basilicum) caused by Peronospora belbahrii by means of resistance inducers, fungicides, biocontrol agents and natural products. Phytoparasitica 41, 59-72.

Gilardi G, Demarchi S, Gullino ML \& Garibaldi A (2015 a) Management of leaf spot of wild rocket using fungicides, resistance inducers and a biocontrol agent, under greenhouse conditions. Crop protection 71, 39-44.

Gilardi G, Demarchi S, Ortu G, Gullino ML \& Garibaldi A (2015 b) Occurrence of Alternaria japonica on seeds of wild and cultivated rocket. Journal of Phytopathology 163, 419-422.

Gilardi G, Franco-Ortega S, van Rijswick P, Ortu G, Gullino ML, Garibaldi A (2017 a) A new race of Fusarium oxysporum f.sp. lactucae of lettuce. Plant Pathology 66, 677-688.

Gilardi G, Gisi U, Garibaldi A \& Gullino M L (2017 b) Effect of elevated atmospheric $\mathrm{CO}_{2}$ and temperature on the chemical and biological control of powdery mildew of zucchini and the Phoma leaf spot of leaf beet. European Journal of Plant Pathology 148, 229-236.

Gilardi G, Pintore I, Demarchi S, Gullino ML \& Garibaldi A (2015 c) Seed dressing to control downy mildew of basil. Phytoparasitica 44, 531-539

Gilardi G, Pintore I, Gullino ML \& Garibaldi A (2017 e) Occurence of Fusarium equiseti as a contaminant of Diplotaxis tenuifolia seeds. Journal of Plant Pathology 99, 245-248. 
Gilardi G, Pons C, Gard B, Franco-Ortega S \& Gullino ML (2017 d) Presence of Fusarium wilt, incited by Fusarium oxysporum f.sp. lactucae, on lettuce in France. Plant Disease 101, 1053.

Gilardi G, Pugliese M, Chitarra W, Ramon I, Gullino ML \& Garibaldi A (2016 a) Effect of elevated atmospheric $\mathrm{CO}_{2}$ and temperature increases on the severity of basil downy mildew caused by Peronospora belbahrii under phytotron conditions. Journal of Phytopathology 164, 114-121

Gilardi G, Webb K, Ortu G, Gullino ML \& Garibaldi A (2016 b) Development of a rapid in planta detection method for identifying Plectosphaerella cucumerina on wild rocket by real-time PCR. Phytopathologia Mediterranea 55, 285-292

Gordon \& Koike (2015) Management of Fusarium wilt of lettuce. Crop Protection 73, 45-49.

Goswami RS, Dong Y \& Punja ZK (2008) Host range and mycotoxin production by Fusarium equiseti isolates originating from ginseng fields. Canadian Journal Plant Pathology 30, 155-160.

Gullino ML, Gilardi G \& Garibaldi A (2014 a) Seed-borne pathogens of leafy vegetable crops. In Global perspectives on the health of seeds and plant propagation material (Eds Gullino ML \& Munkvold G), pp. 47-53. Springer, Dordrecht, The Netherlands.

Gullino ML, Gilardi G \& Garibaldi A (2014 b) Chemical and Non Chemical Seed Dressing for Leafy Vegetable Crops. In Global perspectives on the health of seeds and plant propagation material (Eds Gullino ML \& Munkvold G), pp. 125-136. Springer, Dordrecht, The Netherlands.

Gullino ML, Gilardi G \& Garibaldi A (2017 a) Effect of a climate change scenario on Fusarium equiseti leaf spot on wild rocket and radish under phytotron simulation. Phytoparasitica 45, 293298.

Gullino ML, Gilardi G \& Gatribaldi A (2017 b) Evaluation of the severity of leaf spot of lettuce, caused by Allophoma tropica, under a climate change scenario. Phytopathologia Mediterranea 56, $235-241$.

Gullino ML, Stack J, Fletcher J \& Mumford J (2017 c) Practical Tools for Plant and Food Biosecurity, pp. 384. Springer, Dordrecht, The Netherlands.

IFPA (2001) International Fresh-cut Produce Association. "Fresh-cut Produce: Get the Facts!" www.fresh-cuts.org (Last accessed 2/April 2017).

Katan J (2017) Diseases caused by soilborne pathogens: biology, management and challenges. Journal of Plant Pathology 99, 305-315.

Kenigsbuch D, Chalupowicz D, Aharon Z, Maurer D, Ovadia A \& Aharoni N (2010) Preharvest solar heat treatment for summer basil (Ocimum basilicum) affects decay during shipment and shelf life. Acta Horticulturae 880, 161-166. 
Koch E \& Roberts SJ (2014) Non-chemical seed treatment in the control of seed-borne pathogens. In Global perspectives on the health of seeds and plant propagation material (Eds Gullino ML \& Munkvold GP), pp. 105-123. Springer, Dordrecht, The Netherlands.

Leadbeater A \& Gisi U (2010) The challenges of chemical control of plant diseases. In Recent Developments in Management of Plant Diseases (eds Gisi U, Chet I \& Gullino ML), pp 3-17. Springer Science + Business Media, Dordrecht, The Netherlands.

Lopez-Reyes GG, Gilardi G, Garibaldi A \& Gullino ML (2016) In vivo evaluation of essential oils and biocontrol agents combined with heat treatments on basil cv Genovese Gigante seeds against Fusarium oxysporum f. sp. basilici. Phytoparasitica 44, 35-45.

Matheron M \& Gullino ML (2012) Fusarium wilt of lettuce and other salad crops. In Fusarium wilt of greenhouse vegetable and ornamental crops (Eds Gullino ML, Katan J, Garibaldi A), APS Press St. Paul, MN, USA.

Matta A \& Garibaldi A (1981) Malattie delle piante ortensi. Edagricole, Bologna (Italy).

Mbofung GCY \& Pryor BM (2010) A PCR-based assay for detection of Fusarium oxysporum f. sp. lactucae in lettuce seed. Plant Disease 94, 860-866.

Mersha Z, Zhang S, Fu YQ, Mo XD, Raid RN \& Hau B (2013) Efficacy of acibenzolar-S-methyl and $\beta$-aminobutyric acid for control of downy mildew in greenhouse grown basil and peroxidase activity in response to treatment with these compounds. Journal of Phytopathology 161, 154-164.

Mumford JD, Gullino ML, Stack J, Fletcher J \& Quinlan MM (2017) Practical Tools for Plant and Food Biosecurity. In The need for international perspectives to solve global biosecurity challenges (Eds Gullino M.L., Stack J., Fletcher J., Mumford J.), pp. 363-384. Springer, Dordrecht, The Netherlands.

Munkvold GP (2009) Seed pathology progress in the academia and industry. Annual Review of Phytopathology 47, 285-311.

Nathaniels NQR (1985) Phoma valerianellae on corn salad. Plant Pathology 34, 449-450.

Neergaard P (1979) Seed Pathology. Volume I and II. MacMillan Press, London, 1191 pages.

Nega E, Ulrich R, Werner S \& Jahn M (2003) Hot water treatment of vegetable seed - an alternative seed treatment method to control seed-borne pathogens in organic farming. Journal of Plant Disease and Protection 110, 220-234.

Nguyen TH, Mathur SB \& Neergaard P (1973) Seed-borne species of Myrothecium and their pathogenic potential. Transactions of the British Mycological Society 61, 347-354.

Nomisma (2015) Rapporto sulla competitività del settore ortofrutticolo nazionale. Agra Editrice srl.

iris-AperTO 
Norman DJ, Henny RJ, Yuen JMF, Mellich TA (2003) Screening for resistance to Myrothecium leaf spot among Syngonium species and cultivars. Hort Science 38, 75-76.

O'Donnell K, Humber RA, Geiser DM, Kang S, Park B, Robert VA, Crous PW, Johnston PR, Aoki, T, Rooney AP, Rehner SA (2012) Phylogenetic diversity of insecticolous fusaria inferred from multilocus DNA sequence data and their molecular identification via FUSARIUM-ID and FUSARIUM MLST. Mycologia 104, 427e445.

Ojiambo P S, Yuen J, van den Bosch F \& Madden LV (2017) Epidemiology: Past, Present, and Future Impacts on Understanding Disease Dynamics and Improving Plant Disease Management-A Summary of Focus Issue Articles. Phytopathology 107, 1092-1094.

Palm ME, Gams W \& Nirenberg HI (1995) Plectosporium, a new genus for Fusarium tabacinum, the anamorph of Plectosphaerella cucumerina. Mycologia 87, 397-406.

Pasquali M, Demathei F, Gullino M L \& Garibaldi A (2007) Identification of Race 1 of Fusarium oxysporum f. sp. lactucae on Lettuce by Inter-Retrotransposon Sequence-Characterized Amplified Region Technique. Phytopathology 97, 987-996.

Pétriacq P, Stassen J HM \& Ton J (2016) Spore density determines infection strategy by the plant pathogenic fungus Plectosphaerella cucumerina. Plant Physiology 170, 2325-2339.

Pintore I, Gilardi G, Gullino ML \& Garibaldi A (2016) Detection of mefenoxam-resistant strains of Peronospora belbahrii, the causal agent of basil downy mildew, transmitted through infected seeds. Phytoparasitica 44, 563-569.

Pintore I, Gilardi G, Gullino ML \& Garibaldi A (2017) Efficacy of different fungicides against the leaf spot of lettuce caused by Allophoma tropica. Journal of Plant Disease and Protection, submitted.

Punja ZK, Wan A, Rahman M, Goswami RS, Barasubiye T, Seifert KA, \& Lèvesque CA (2008) Growth, population dynamics, and diversity of Fusarium equiseti in ginseng fields. European Journal of Plant Pathology 121, 173-184.

Rimmer SR, Shattuck VI \& Buchwaldt L (2007) Compendium of Brassica Diseases. APS Press, New York.

Schneider R \& Boerema GH (1975) Phoma tropica n. sp. Ein an Gewächshauspflanzen häufig vorkommender, nicht pathogener. Phytopathologische Zeitschrift Journal of Phytopathology 83, 362-366.

Segarra G, Sant D, Trillas MI, Casanova E, Noguera R, Castillo S, Borrero C \& Avilés M (2013) Efficacy of the microbial control agent Trichoderma asperellum strain T34 amended to different growth media against soil and plant leaf pathogens. Acta Horticolturae 1013, 515-520. 
Siciliano I, Berta F, Bosio P, Gullino ML \& Garibaldi A (2017 a) Effect of different temperatures and $\mathrm{CO}_{2}$ levels on Alternaria toxins produced on cultivated rocket, cabbage and cauliflower. World Mycotoxin Journal 10, 63-71

Siciliano I, Bosio P, Gilardi G, Gullino ML \& Garibaldi A (2017 b) Verrucarin A and roridin E produced on spinach by Myrothecium verrucaria under different temperatures and $\mathrm{CO}_{2}$ levels. Mycotoxin Research 33,139-146

Siciliano I, Gilardi G, Ortu G, Gisi U, Gullino ML \& Garibaldi A (2017 c) Identification and characterization of Alternaria species causing leaf spot on cabbage, cauliflower, wild and cultivated rocket by using molecular and morphological features and mycotoxin production. European Journal of Plant Pathology 149, 401-413.

Simmons EG (2007) Alternaria: An Identification Manual. CBS Fungal Biodiversity Centre. Utrecht, The Netherlands.

Stoate C, Baldi A, Beja P, Boatman ND, Herzon I, van Doorn A, de Snoo GR, Rakosy L \& Ramwell C (2009) Ecological impacts of early 21stcentury agricultural change in Europe. A review. Journal of Environmental Management 91, 22-46.

Taba S, Takara A, Nasu K, Miyahira N, Takushi T \& Moromizato Z (2009) Alternaria leaf spot of basil caused by Alternaria alternata in Japan. Journal of General Plant Pathology 75, 160-162.

Thines M., Telle S, Ploch S, \& Runge F (2009) Identity of the downy mildew pathogens of basil, coleus, and sage with implications for quarantine measures. Mycological Research 113, 532-540.

Thomas JE, Wood TA, Gullino ML \& Ortu G (2017) Diagnostic tools for plant biosecurity. In Practical Tools for Plant and Food Biosecurity (Gullino M.L., Stack J., Fletcher J., Mumford J.), pp 209-226. Springer, Dordrecht, The Netherlands.

Tidwell TE, Blomquist CL \& Rooney-Latham S (2014) Leaf Spot of arugula, caused by Alternaria japonica, in California. Plant Disease 98, 1272.

West JS, Townsend JA, Bruce MS, Fitt DL (2012) Comparative biology of different plant pathogens to estimate effects of climate change on crop diseases in Europe. European Journal of Plant Pathology 133, 315-331

Wyenandt CA, Simon JE, Pyne RM, Homa K, McGrath MT, Zhang S, Raid RN, Ma LJ, Wick R, Guo L \& Madeiras A (2015) Basil Downy Mildew (Peronospora belbahrii): discoveries and challenges relative to its control. Phytopathology 105,885-94.

Yang S-M \& Jong SC (1995) Host range determination of Myrothecium verrucaria isolated from leafy spurge. Plant Disease 79, 994-997. 
Youssef YA, el-Tarabily KA \& Husssein AM (2001) Plectosporium tabacinum root rot disease of white lupine (Lupinus termis Forsk.) and its biological control by Streptomyces species. Journal of Phytopathology 149, 29-33.

Zadoks JC (2017) On social and political effects of plant pest and disease epidemics. Phytopathology 107, 1144-1148. 
Table 1 - Main foliar pathogens on leafy vegetables first reported in Italy during the past few years (adapted from Gullino et al., 2014 a).

\begin{tabular}{|c|c|c|c|}
\hline Host & Species & Pathogen & $\begin{array}{l}\text { First year of } \\
\text { detection, region }\end{array}$ \\
\hline \multirow{3}{*}{$\begin{array}{l}\text { Cultivated } \\
\text { rocket }\end{array}$} & \multirow[t]{3}{*}{ Eruca vesicaria } & Alternaria japonica & 2010, Piedmont \\
\hline & & Fusarium equiseti & 2011, Piedmont \\
\hline & & Colletotrichum kahawae & 2014, Piedmont \\
\hline \multirow[t]{3}{*}{ Wild rocket } & \multirow[t]{3}{*}{ Diplotaxis tenuifolia } & Alternaria japonica & 2010, Liguria \\
\hline & & Plectosphaerella cucumerina & 2012, Campania \\
\hline & & $\begin{array}{l}\text { Fusarium equiseti } \\
\text { Myrothecium verrucaria }\end{array}$ & $\begin{array}{l}\text { 2014, Campania } \\
\text { 2015, Lombardy }\end{array}$ \\
\hline \multirow[t]{3}{*}{ Lettuce } & \multirow[t]{3}{*}{ Lactuca sativa } & Allophoma tropica & 2011, Lombardy \\
\hline & & $\begin{array}{l}\text { Fusarium equiseti } \\
\text { Pythium Cluster B2a }\end{array}$ & 2014, Veneto \\
\hline & & $\begin{array}{l}\text { (P.dissotocum, P. coloratum, } P . \\
\text { diclinum, } P . \text { cf. dictyosporum, } P . \\
\text { lutarium, } P . \text { sp. 'Group F' and } P . s p . \\
\text { tumidum) }\end{array}$ & 2015, Lombardy \\
\hline \multirow{4}{*}{$\begin{array}{l}\text { Lamb’s } \\
\text { lettuce }\end{array}$} & \multirow[t]{4}{*}{ Valerianella olitoria } & Phoma valerianellae & 1966, Liguria \\
\hline & & Pythium irregulare & 2013, Piedmont \\
\hline & & Plectosphaerella cucumerina & 2014, Campania \\
\hline & & Myrothecium roridum & 2015, Lombardy \\
\hline Basil & Ocimum basilicum & Alternaria alternata & $\begin{array}{l}\text { 2010, Piedmont, } \\
\text { Liguria }\end{array}$ \\
\hline \multirow[t]{2}{*}{ Swiss chard } & \multirow{2}{*}{$\begin{array}{l}\text { Beta } \\
\text { vulgaris subsp. vulgaris }\end{array}$} & Pleospora betae & 2007, Piedmont \\
\hline & & Pythium aphanidermatum & 2010, Piedmont \\
\hline \multirow[t]{4}{*}{ Spinach } & \multirow[t]{4}{*}{ Spinacia oleracea } & & \\
\hline & & Fusarium oxysporum f.sp. spinacie & 2011 Campania \\
\hline & & Pythium aphanidermatum & 2014 Campania \\
\hline & & Myrothecium verrucaria & 2015 Lombardy \\
\hline
\end{tabular}


Table 2 Contamination of lettuce, rocket, corn salad, spinach and basil seeds by some fungal pathogens of leafy vegetable crops (adapted from Gullino et al., 2014 b).

\begin{tabular}{|c|c|c|c|}
\hline Host & Pathogen & $\begin{array}{l}\% \text { of contaminated } \\
\text { seeds }\end{array}$ & Seed treatments \\
\hline Lettuce & $\begin{array}{l}\text { Fusarium oxysporum f. } \\
\text { sp. lactucae }\end{array}$ & 0.1 & $\begin{array}{l}\text { Physical, chemical, biological, thyme oil seed } \\
\text { treatments; resistant inducers (i.e. acibenzolar- } \\
\text { S-methyl), }\end{array}$ \\
\hline Rocket & Fusarium oxysporum & 0.1 & $-*$ \\
\hline Wild rocket & $\begin{array}{l}\text { Plectosphaerella } \\
\text { cucumerina }\end{array}$ & 0.15 & - \\
\hline Lamb's lettuce & Phoma valerianellae & $0.6-15$ & Aerated steam, hot water, thyme oil \\
\hline Basil & $\begin{array}{l}\text { Fusarium oxysporum f. } \\
\text { sp. basilici }\end{array}$ & $\begin{array}{l}0.4 \quad \text { (external } \\
\text { contamination) } \\
0.2 \quad \text { (embrio } \\
\text { contamination) }\end{array}$ & $\begin{array}{l}\text { Dry hot air, thyme oil; chemical, biological seed } \\
\text { treatments }\end{array}$ \\
\hline Basil & Alternaria alternata & $\begin{array}{l}0.2-15.0 \text { (external } \\
\text { contamination) } \\
0.2-2.0 \quad \text { (embrio } \\
\text { contamination) }\end{array}$ & - \\
\hline Basil & Peronospora belbahrii & 0.01 & $\begin{array}{l}\text { Dry hot air, thyme oil, resistant inducers (i.e. } \\
\text { potassium phosphite or acibenzolar-S-methyl), }\end{array}$ \\
\hline $\begin{array}{l}\text { Wild and } \\
\text { cultivated }\end{array}$ & Alternaria japonica & $\begin{array}{l}0.4 \quad \text { (external } \\
\text { contamination) }\end{array}$ & - \\
\hline rocket & & $\begin{array}{l}0.2 \quad \text { (embrio } \\
\text { contamination) }\end{array}$ & \\
\hline Wild rocket & Fusarium equiseti & $\begin{array}{l}0.6 \% \quad \text { (external } \\
\text { contamination) }\end{array}$ & - \\
\hline
\end{tabular}

*N.t. Data not available 
Figures

Figure 1 Symptoms caused by Plectosphaerella cucumerina on Diplotaxis tenuifolia.



Figure 2 Necrotic spots caused by Plectosphaerella cucumerina on endive.

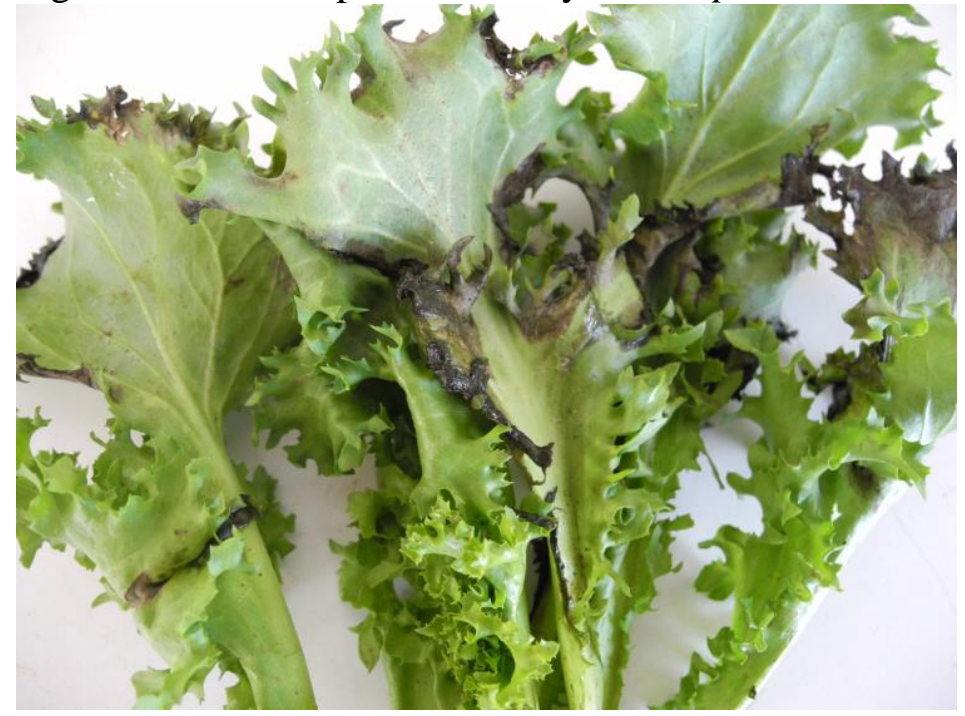


Figure 3 Alternaria leaf spot on basil.

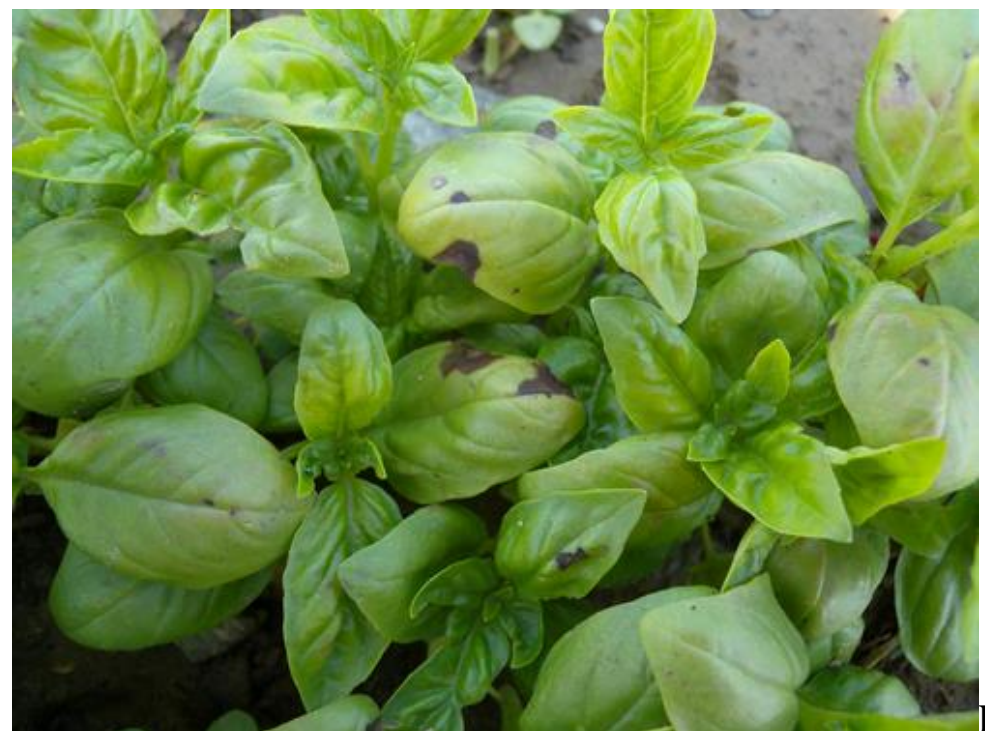

Figure 4 Leaf spot caused by Alternaria

japonica on Eruca vesicaria.

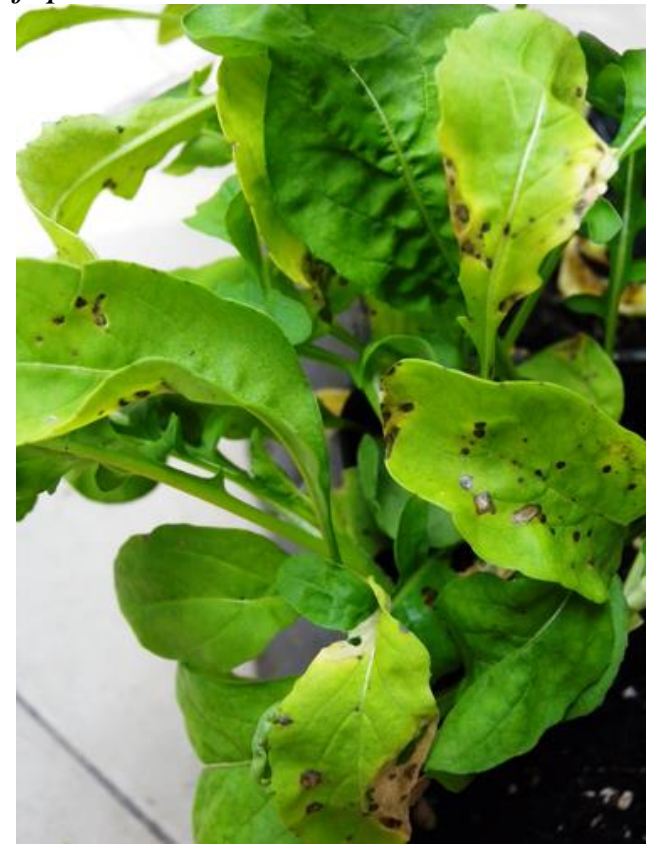

iris-AperTO

University of Turin's Institutional Research Information System and Open Access Institutional Repository 
Figure 5 Leaf spot caused by Fusarium equiseti on Diplotaxis tenuifolia.

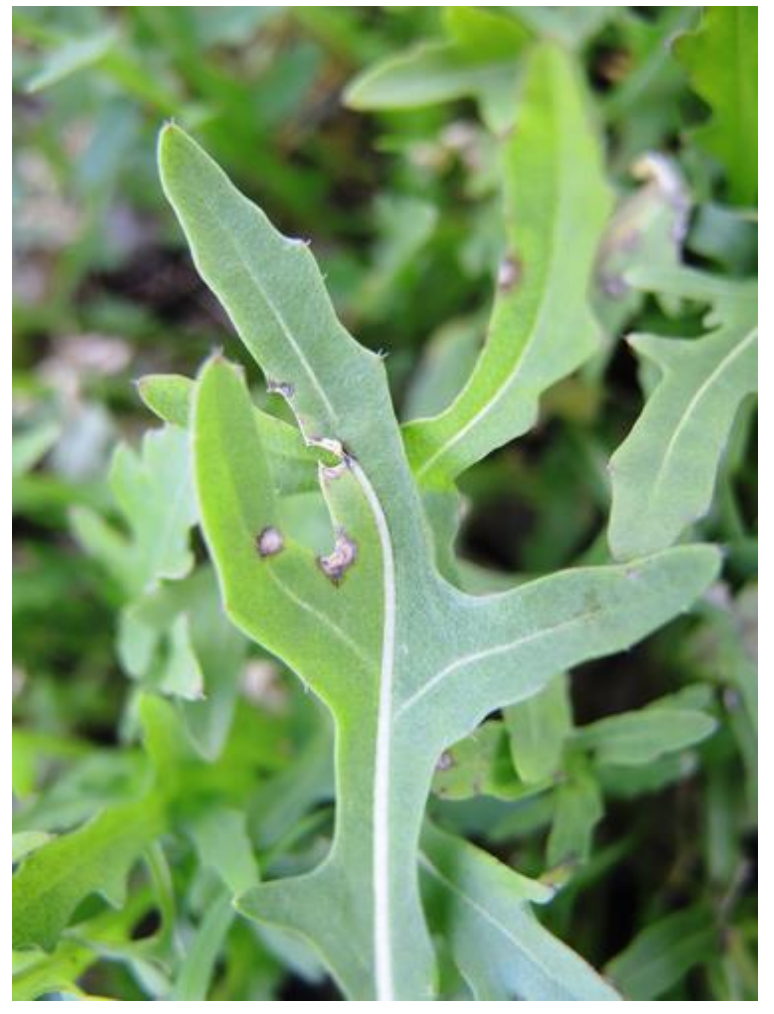

Figure 6 Details of necrosis caused by Fusarium equiseti on lettuce.

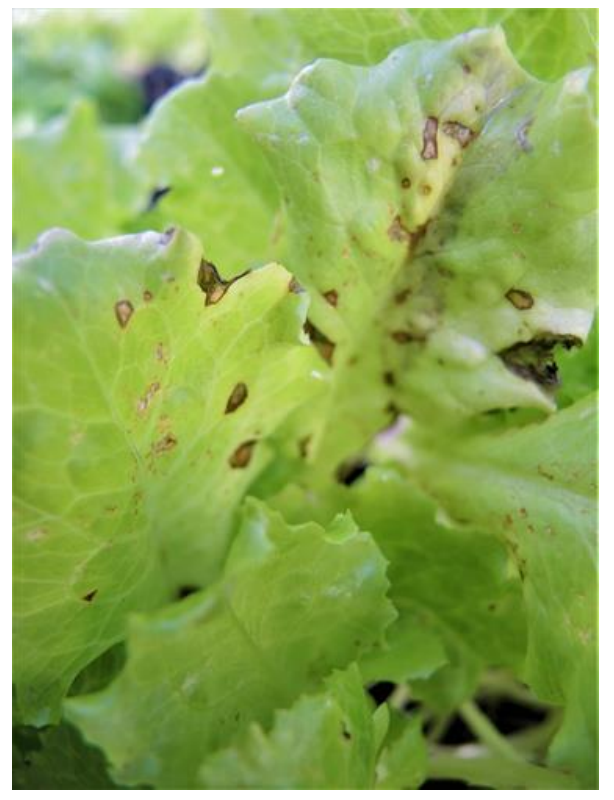


Figure 7 Leaf necrosis on lamb's lettuce caused by Myrothecium roridum.

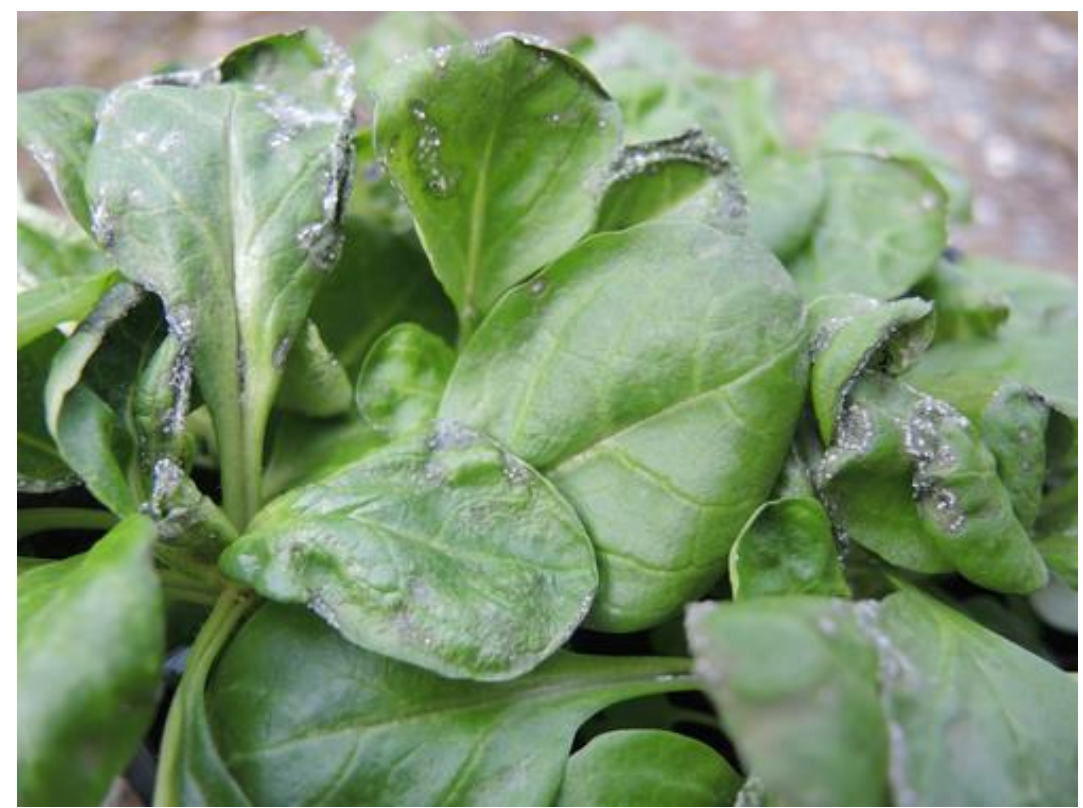

Figure 8 Leaf necrosis on spinach caused by Myrothecium verrucaria.

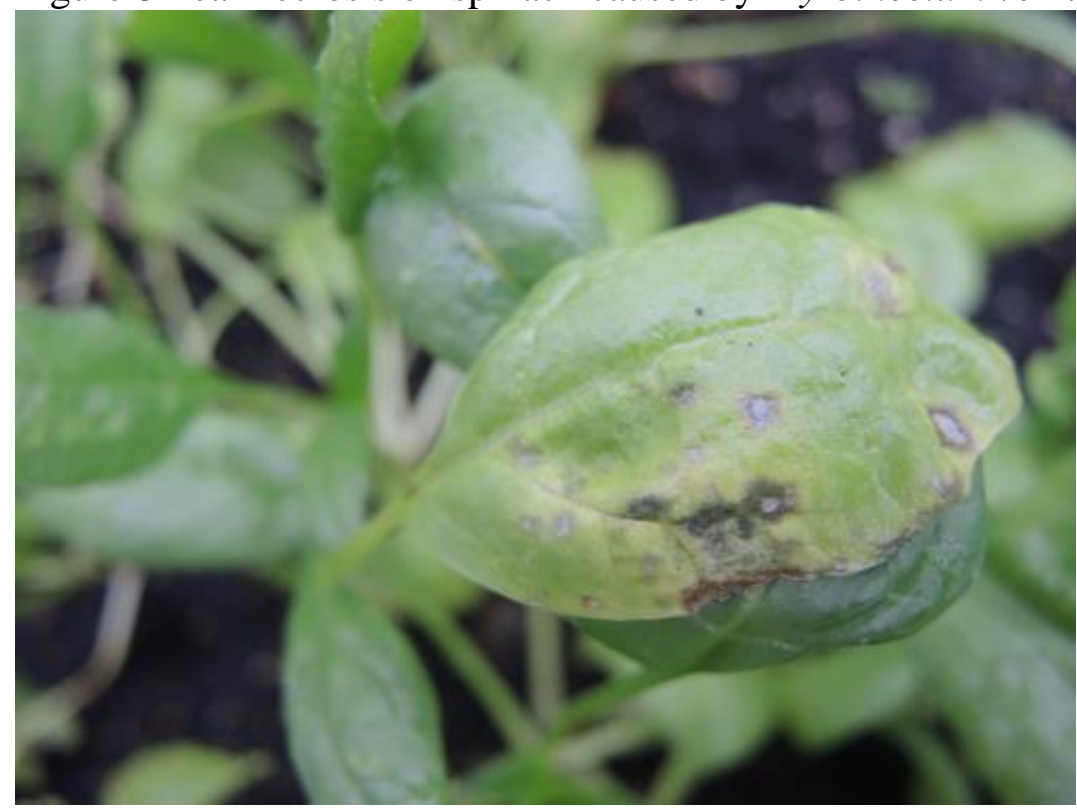

iris-AperTO

University of Turin's Institutional Research Information System and Open Access Institutional Repository 
Figure 9 Leaf necrosis on wild rocket caused by Myrothecium verrucaria.

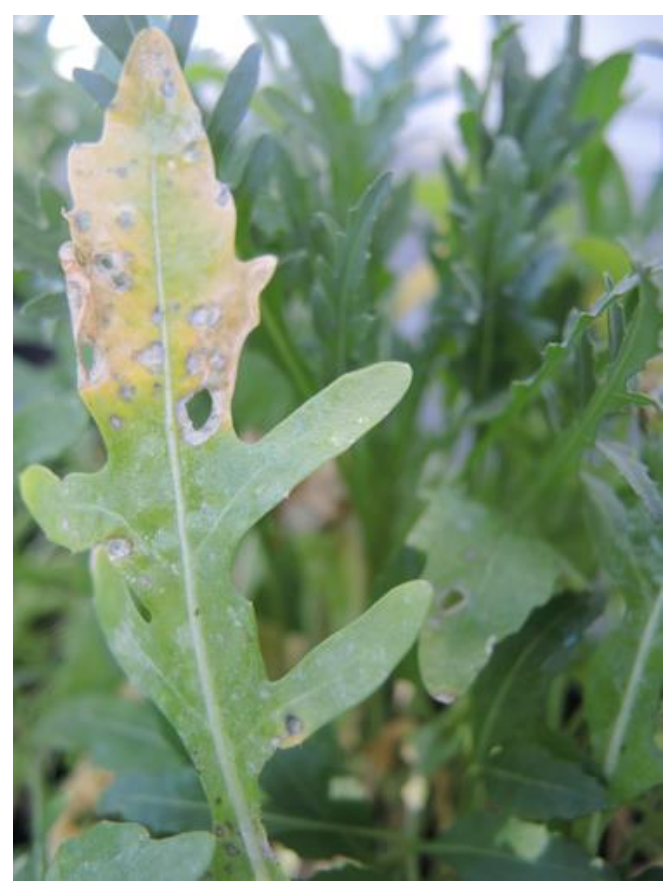

Figure 10 Leaf necrosis on lettuce caused by Allophoma tropica.

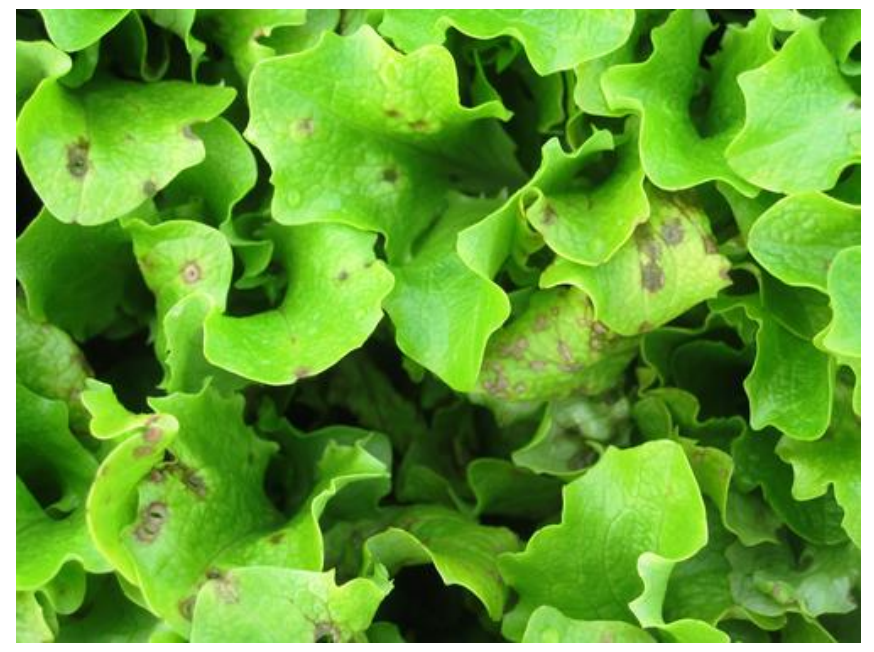

Figure 11 Symptoms caused by Pythium irregulare on lamb's lettuce.

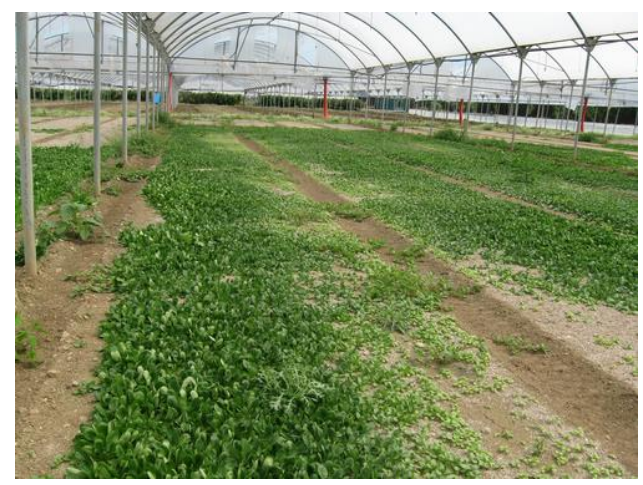


Figure 12 Symptoms caused by Pythium aphanidermatum on spinach.

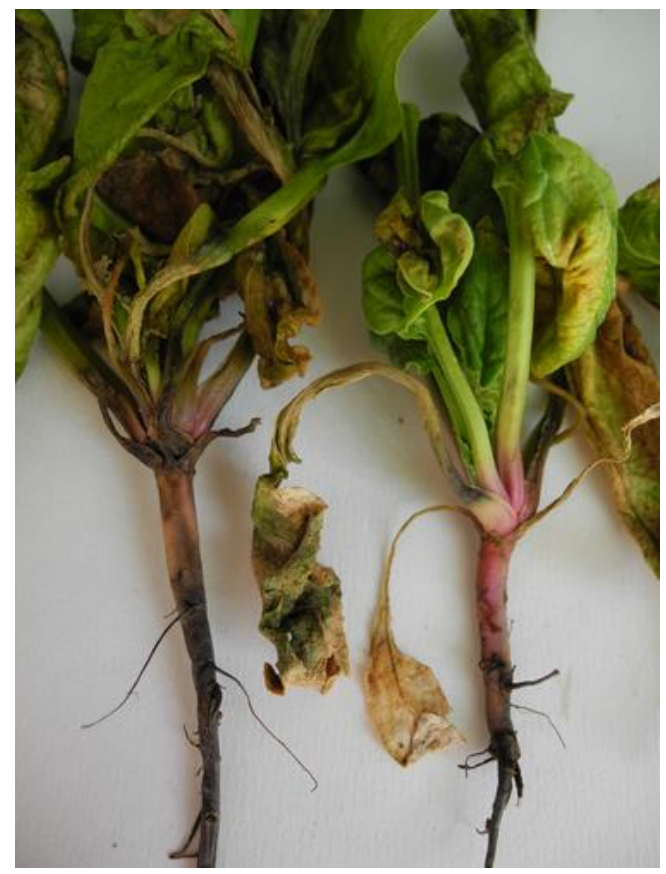

\section{iris-AperTO}

